\title{
Postcolonial Dilemmas in Kiran Desai's The Inheritance of Loss
}

\author{
Abraham Panavelil Abraham \\ University of Nizwa \\ Sultanate of Oman \\ Oman \\ abraham@unizwa.edu.om
}

\begin{abstract}
The paper will try to analyze Kiran Desai's Booker winning novel The Inheritance of Loss as story dealing primarily about the problems of migration faced by her characters, their tensions and dilemmas. One of the major concerns of diasporic literature is the problem of exile, displacement and the resulting consequences. Uprooting from one's own home land is an agonizing process that brings numerous material and emotional traumas in the process of rerooting in an alien land. The characters are often victims of circumstances and by the time they realize the problems, they are exhausted, miserable and frustrated. Even when they come back after their traumatic experiences, like the Judge in the novel, they often develop a sense of distrust and anger. They are in a state of confusion from which they find it difficult to come out. The paper will focus on the experiences of some of the characters in the novel - Jemubhai Patel, the Judge, and Biju, the son of Judge's cook who is the central character of the novel. The book seems to suggest that true happiness does not lie in material wealth or comforts, but in one's own
\end{abstract}


dignity, identity and sense of belonging. In the novel, the characters especially Biju has to undergo number of traumatic experiences that brought a lot of material loss, but he has a spiritual gain- the realization of what brings true joy in life.

Keywords: Alienation, Assimilation, Diaspora, Hybridization, , Identity, Immigrant, , Postcolonial

If we do look back, we must also do so in the knowledge -which gives rise to profound uncertainties -which our physical alienation from India almost inevitably means that we will not be capable of reclaiming precisely the thing that was lost; that we will, in short, create fictions not actual cities or villages, but invisible ones, imaginary homelands, Indias of the mind- Salman Rushdie in Imaginary Homelands

\section{Introduction}

Kiran Desai is an established diasporic writer of Indian origin who presents Indians as protagonists in her fiction. As a diasporic postcolonial writer, Desai tries to depict themes like marginalization, cultural insularity, nostalgia, alienation, quest for identity and assimilation in her characters. Desai was born in India in 1971 and she lived in Delhi till the age of fourteen. Before her family moved to USA, she spent a year in England. She concluded her education in USA. Desai through this novel reflects her experiences and realization in her journey from India to USA. About her novel, Desai remarks, "The characters of my story are entirely fictional, but these journeys ... as well as my own provided insight into what it means to travel between East 
and West and it is this I wanted to capture. The fact that I live this particular life is no accident. It was my inheritance.” (In The Rediff Interview)

The focus of Desai's novel is on Indian immigrants who struggle to settle down in the US. Diasporic writing often deals with a shared identity of being dislocated and is an important theme in postcolonial literature especially writings from Caribbean, Asian American and other countries. It means that national, ethnic or communal identities are constituted in the absence of a territory. For instance, Indians settled in America are those who have an Indian identity though they live and work outside the politico-geographical territory of India. They retain their Indian identity in spite of the loss of a homeland. This is probably the most curious and paradoxical theme in postcolonial diasporic writings.

Ever since Salman Rushdie published his ground breaking novel Midnight's Children ((1981) Indian writings in English have achieved considerable international recognition and visibility to become part of World literature. Curiously, many of these writers belong to a global fraternity of diasporic Indians, appropriately called NRIs ("Non Resident Indians"). Kiran Desai (the daughter of Anita Desai, well known Indian writer in English) who has settled down in America, is one such writer and became famous with her Booker winning novel The Inheritance of Loss

This paper is an attempt to consider the novel under the rubric of postcolonial diasporic fiction. The story is set against the backdrop of the lush and exotic surroundings of Kalimpong and the agitation of Gorkhaland in the north eastern hills of Darjeeling, close to the borderland with Nepal. Set in the 1980s, the novel gives a graphic account of a cross section of Indian society in characters like Jemubhai Patel, a former judge, once an impoverished student in England, who returns to India to a life of colonial service. He is someone who has rejected his 
family and native heritage, choosing instead a life based on an obsessive pursuit of so called colonial ideals. His teenaged granddaughter Sai and their cook, Panna Lal who lives in a house in the north East

Indian town of Kalimpong, Biju, the cook's son, Gyan, Saeed, Haresh Harvy and the two sisters, Lolita and Nonita are other characters. Biju, is an illegal immigrant, living among other immigrants in New York, trying to eke out a living in the basements of one shady restaurant after the other. All these figures are the inheritors of loss in terms of dislocation of place, wealth and progress. They are all transformed from their 'native' identity into something quite different, a 'westernized native'. Rather they are negotiating with a state of non-identity. Caught between two worlds these characters negotiate a new social space' caught between two cultures and often languages, the writer negotiates a new literary space. They are all haunted by the questions posed by an immigrant: Who am I? Where do I belong? It is clear from this cast of uprooted characters that a sense of loneliness and alienation, said to be an integral part of the diasporic condition, is at the core of the novel. They are displaced individuals who struggle to find a space out of place, away from their homelands.

In his well- known essay, titled Imaginary Homeland, Rushdie focuses on the crisis that is created by diasporic experiences to the writers. Here, he throws light on the positive side of diaspora. He argues that the displaced position of the migrant is an entirely valuable one. According to Rushdie, to live as a migrant may well evoke a sense of loss but on the other hand, it opens different windows of possibility to have new knowledge. This diasporic experience can be the source of creativity and can give birth to dignified feelings. The distance between abroad and the mother land may act as a stimulator that makes migrants nostalgic and at the same time sensitive to the respective homeland. 


\subsection{The Epigraph}

Jorge Luis Borges' poem “Boast of Quietness" is used an epigraph for the novel and it acts as an ode of powerlessness of the poor and those treated inhumanely. It speaks of those who are going back and forth between cultures and homeland as characters in the novel, like the Judge (India and England) and like the cook's son Biju to America and then back to India. There are many Indians who seek a better life abroad and the poem wonders if they ever arrive at whatever destination they think they seek. The longing for another culture other than their own makes them feel alienated and displaced. In Borges' poem, boasting and quietness are oxymoron and the poet creates images that are richly layered with meanings. :

"My name is someone and anyone

I walk slowly, like one who comes from so far away he doesn't expect to arrive. ("Boast of Quietness")

Borges' poem deals with the universality and timelessness of human condition whereas The Inheritance of Loss focuses more on specific people living with specific historic and cultural backgrounds.

\section{Who am I? Where do I belong?}

All the characters in Inheritance of Loss suffer from a sense loss and ambivalence that eventually leads them to question their identity. Jemubhai Patel, the former judge, is an embittered person and he often lives in the past. In a flashback, we learn that when he was a young man, he was sent to Cambridge by his family to study law. But, in England, he was ridiculed for his accent. Young English girls held their nose as he passed insisting he reeked of curry- this rejection fuelled in his soul, a shame and dislike for his heritage, his culture and the 
color of his skin. "He retreated into a solitude that grew in weight day by day. The solitude became a habit, the habit became the man, and it crushed him into a shadow" (Inheritance of Loss, 39). The judge, in fact, becomes a victim of "double consciousness" - a term coined by W.E. B. Dubois and used often in postcolonial discourses. [Dubois used this to describe an individual whose identity is divided into several facets]. "He envied the English---He loathed Indians" (119). The judge looks at the

English as someone superior and this attitude of 'colonial hangover' puts him in diasporic dilemma that aggravates his ambivalent nature. In his article "Solid Knowledge and Contradiction in Kiran Desai's Inheritance of Loss, David Wallace Spielman argues that the characters in the novel employ two main strategies-suppression and ambivalence-in order to protect their solid knowledge about what they believe to be true, from the confusing effect of contradictions (75). Therefore Jemubhai prefers suppression in order to maintain his version of truth-the supremacy of the English culture: “To suppress his Indian past and elevate himself above others in his community, the Judge holds fast to what he has learned of performing English identity" (77).

In the case of Gayan, it is dislocation from Nepal that makes him ambivalent. He also faces problem of identity as he loves Gurkhaland but does not fight for it. His love for Sai is also ambivalent and uncertain. Sai is also a victim of circumstances. She lost her parents in an accident in Russia. Her father was a space scientist, living in Russia, while she herself was living in Darjeeling in a convent. So, from the outset she has tasted bitter feelings of separation and displacement. Romantically she decided that love must reside in the gap between desire and fulfillment, in the lack, not the contentment. Love was the ache, the anticipation, the retreat, everything around it, but the emotion itself (2-3). 
She arrives at the house of her grandfather, the retired judge, whom she has never met before.

Her displacement from the comforts of a convent school in Darjeeling to the lush, misty Himalayan region of Kalimpong in North Eastern India, where growing Nepalese insurgency is about to unravel her life further, brings a lot of havoc in her life. The love between Sai and Gyan, her math's tutor, though flowers in the beginning; it dies when Gyan joins the insurgents and stops coming to see her. Sai eventually goes to confront him, but the meeting ends in disappointment with the result that both of them get alienated from each other.

Her desire to achieve a kind of emotional bond with her grandfather, the retired judge, also fails, for he himself is displaced emotionally and physically- the tension between wanting to belong to his own native land and a foreign culture, the usual post-colonial/diasporic dilemma. The first evening when Sai was at Cho Oyu at her grandfather's home "she had a fearful feeling of having entered a space so big it reached both backward and forward" (34). Desai often uses such binary opposites like arrivals and departures move in and move out, hope and hopelessnessall part of the diasporic problem.

\subsection{A Sense of Displacement and Assimilation}

The displacement of Biju, the son of the cook is more poignant than any other characters in the novel. He manages to get a tourist visa. Biju, who joins a crowd of Indians scrambling to reach the visa counter at the US embassy, is one of the most troublesome scenes in the novel.

Eventually, Biju becomes an illegal immigrant in New York, does some odd jobs, "Biju changed jobs like a fugitive on the run" (3). On the contrary, his father, back in India thinks that he is doing well and is proud of the fact that his son is in America. "He works for the Americans; the cook has reported the content of the letter to everyone in the market" (14). The irony of the 
situation is that for Biju America is a world of frustration and hopelessness. He was taken to America as a mechanic but ended up as a waiter in a restaurant. His friend Sayeed has a comfortable life in America. He has not been affected by the frustrations of an immigrant. While Biju is a lost man in the new world, Sayeed is very adaptable and can lead a life without any qualms. Biju's longing for home is continu ous from the beginning, while Sayeed never thinks of leaving America.

Biju was so restless sometimes; he could barely stand to stay in his skin. After work, he crossed the river, not to the part where the dogs played madly in hanky-sized squares, with their owners in the fracas picking up feces, but to where, after singles, night at the synagogue, long-skirted-and sleeved girls walked in an old fashioned manner with the old-fashioned looking men wearing black suits and hats as if they has to keep their past with them at all times so as not to lose it. He walked to the far end where the homeless man often slept in a dense chamber of green that seemed to grow not so much from soil as from a fertile city crowd. A homeless chicken also lived in the park. Every now and then Biju saw it scratching in a homey manner in the dirt and felt a pang for village life (81)

Sayeed is, in fact a foil to Biju. The two characters are juxtaposed together to show the difference between two types of immigrants. Sayeed does not react to Biju with suspicion or hatred, like the Pakistanis that Biju had worked with. America is a 'melting pot' for Sayeed. But he is also on the horns of a dilemma as there are conflicts in his mind about his identity. He explains why he does not eat pork, "First I am Muslim, then I am Zanzibari, then I will be American" (136). He is, in fact, not a true Muslim. He marries a woman just to get a green card. $\mathrm{He}$, then tells Biju that he has met another woman, visiting from Zanzibar, whom he intends to 
marry---in four years I get my green card and ---out there---I get divorced and I marry for real" (318). He is prepared to go to any extreme to get a green card even at the cost of his self-respect.

Desai compares Biju and Sayeed to show how they handle the same dilemmas of an immigrant in an alien land. Sayeed seems to be more practical while Biju is very sensitive to such changes and resists the Western culture in which he is trapped in and longs for his home back in India. Desai seems to suggest that people like Biju faces repeated miseries and misfortunes and those like Sayeed learn to survive in a foreign culture without any qualms. Even the minor characters like Noni, Lola, Uncle Potty, Princess Mrs. San and Munmun are all exiles who are inheritors of loss. They are all affected by a sort of imbalance by leading a dual life which profoundly affects their thoughts and feelings. All are diasporic characters who are forced into contact with cultures in conflict. They are all trapped by their peculiar ambivalent environment that they are forced into. This, according to Radhakrishnan,"leads to a loss of selfesteem; but more importantly, it leads to a loss of moorings and this is a greater loss because the characters are displaced at home.

This makes home a diaspora and the loss of identity and self-esteem makes it a volatile space". (313).

\subsection{Memory and Nostalgia}

Memory and nostalgia play an important role in postcolonial, diasporic literature. In this novel also, Biju, has nostalgic feelings about is childhood back in his village in India. The Jamuna River and the men traveling downstream on inflated buffalo skins bring nostalgic thoughts of his childhood. Biju recalls his grandmother and how she has crossed on market trips into towns and back, with a sack of rice on her head. He also remembers the hermit who also 
lived there, waiting for the glint of another, an allusive mystical fish: "On Diwali the holy man lit lamps and put them in the branches of the peepal tree and sent them down the river on rafts with marigolds - how beautiful the sight of those lights bobbing in that young dark. When he had visited his father in Kalimpong, they had sat outside in the evenings and his father remembered: "How peaceful our village is. How good the roti tastes there! It is because the atta is ground by hand, not by machine... and because it is made on choolah, butter, and fresh milk still warm from the buffalo---"They had stayed up late. They had not noticed Sai, then aged thirteen, staring from her bedroom window, jealous of the cook's love for his son. Small red-mouthed bats drinking from the jhora had swept over again and again in a witch flap of black wings (103).

The judge's story is mostly told through his memory and brought on by his interaction with his granddaughter, Sai and her math tutor and lover Gyan. In a flashback, he tries to contrast his native Indian scene with that of his stay in England. But the difference is that his attitude is one of ambivalence. He starts his journey from Pilhit to London with the hope of qualifying himself for the ICS examination. He bought the old house from a Scots man who told him, "it is very isolated but the land has potential "for quinine, sericulture, cardamom, orchids (28). However, he was not interested in agricultural possibilities" but could live here "with the solace of being a foreigner in his own country" (29). By purchasing a house, the judge shows his desire to settle in his own country but he feels like a foreigner in his own country and this shows his sense of alienation.

After independence, the judge found himself on the wrong side of history. The judge's marriage to Nimi was a complete failure. He never had any soft feeling for his wife though her parents had paid for his education in England. He felt guilty after her death. "Now Jemubhai 
wondered if he had killed his wife for the sake of false ideals (210). Memory of those past events brings a lot of guilt feelings in him and that is one of the reasons for his loneliness and alienation.

He realized to his surprise, that he was thinking of his own journeys, of his own arrivals and departures, from places far in his past. He has first left home at the age of twenty, with a black tin trunk just like the one Sai had arrived with, on which white letters read "Mr. J.P.Patel, SS

Strathnaver". The year was 1939. The town he had left was his ancestral home of Piphit, and from Liverpool he had gone to Cambridge (35)

He was vacillating between hope and hopelessness- hope to become an ICS and hopelessness regarding his sense of betrayal to his wife: "He thought of his wife. He was a onemonth married man. He would return---many years from now---and then what? ---It was all very strange. She was fourteen years old and he had yet to properly examine her face "(36). When he reached England, he was confused and realized that England of his dreams was quite different from

England of reality: "He continued to be amazed by the sights that greeted him. The England in which he searched for a room to rent was formed of tiny gray houses in gay streets, stuck together and down as if on a glue trap. It took him by surprise because he'd expected only grandness, hadn't realized that her too, people could be poor and live and aesthetic life" (38).

Eventually, "he retreated into a solitude that grew in weight day by day. The solitude became a habit, the habit became the man and it crushed him into a shadow" (39).

It is in England that he developed an inferiority complex and shame on his own heritage and darker skin and he experiences bitterness over the background of his birth. The magnitude of this shame increases as days pass by and the harrowing scene of his civil service examination 
encapsulates it well. In it the judge is forced to recite a poem from memory, but his recitation, riddled with heavy accent, only manages to amuse his examiners: "when he looked up, he say they were all chuckling” (124). According to Uma Jayaraman,

The judge's inability to accept the real presence of his native culture and his "partial presence

"(Bhabha 58), in the much coveted British culture leaves him in the luminal position between borders with an irreversible sense of loss. His life became entrapped in a state of emotional violence within a space of displacement or Diaspora (9).

\subsection{In Search of Safety and Security}

All immigrants especially in the beginning of their settlement are very much concerned about their safety and security in a foreign land. In the initial stages, they are dependent on their relatives or friends who are settled there years ago. In the case of Biju, he has neither relations nor friends who can support him. He has to fight his battle on his own terms. His relation with Harish Harry shows how much he is concerned about his safety and security in a foreign land. He was punished for a mistake that he has not committed. Harish Harry threw him out into the streets of New York mercilessly. He broke his leg and Harish Harry wants Biju to go back to India. Eventually, Biju became a broken man both emotionally and materially. Finally, he decides to return to India which is once again a harrowing experience. Back in India, he finds that the GNLF struggle is in progress. His father does not know that his son is coming back to India for good. His father goes to Kalimpong to know about his son, from whom all forms of communication have stopped owing to the GNLF agitation. He fears that his son is no more! 
Finally, when he reaches Kalimpong, Biju does not find his father. On the way, he was attacked by some thugs who had robbed away whatever money he had and other possessions:

Biju sat there in terror of what he had done. Of being alone in the forest, and of the men coming after him again. He couldn’t stop thinking of all that he had bought and lost. Of the money he'd hidden under fake soles in his shoes of his wallet. Suddenly, he felt an old throbbing of the knee that he had hurt slipping on Harish Harry's floor (318).

In The Location of Culture, Homi Bhabha discusses the detrimental effects of migration and diaspora which call for gathering in a different place, far from what immigrants continue refers to as Home. According to him, the experience of migrating to a new land involves "gathering the signs of approval an acceptance, degrees, discourses, disciplines, gathering the memories of underdevelopment, of other worlds lived retroactively; gathering the past in a ritual of revival; gathering the present" (1994).

The characters in Desai's novel are negotiating the boundaries of their past, present, and future. Bhabha points out that "There is a simultaneous fracturing of identity going on here [in postcolonial/diasporic situations] in terms of both ethnicity and gender which is true of multiculturalism" (57).

The term 'hybridity' is an important concept in postcolonial theory. It refers to the integration of two different cultures. What is hybridization? Bakhtin asks "it is a mixture of two social languages within the limits of a single utterance, an encounter within the arena of an utterance, between two different linguistic consciousnesses, separated from one another by an epoch, by social differentiation, or by some other factors "(300). Bakhtin seems to have used the term: hybridity" as a positive, enriching and dynamic phenomenon. But for Desai, the 
transformation is not necessarily a positive phenomenon, but may have far reaching psychological consequences.

3. Playing with the language

Language is one of the central concerns of postcolonial literatures. Like other postcolonial writers, Desai too plays with the language, using local Hindi dialects and the socalled (Hi) nglish. She uses the multi-leveled meanings of metaphor to capture the essentials of her characters in new thoughts and feelings. She often uses clichés and Indian stereotypes that have been promoted by the Hindi cinema. His use of Hindi language and songs and mention of Indian actors in the framework of the novel gives a touch of authenticity and local color to the story and the characters. For example, the use of Hindi words like "Namaste", Dhanyawad, Shukaria etc and sometimes vulgar, colloquial like "bhenchoots" and other vernacular expressions are used effectively in the novel. Postcolonial writers often take liberty to have the flexibility of using the English language according to the situations where their characters are put in.

Salman Rushdie comments on how working in new Englishes can be a therapeutic effect of resistance, remaking a 'colonial language to reflect the postcolonial experience. In his famous essay "Imaginary Homelands", he explains that far from being something that can simply be ignored or disposed of, the English language is the place where writers can and must work out the problems that confront emerging recently independent colonies:

"One of the changes (in the location of Anglophone writers of Indian descent) has to do with attitudes towards the use of English. Many have referred to the argument about the appropriateness towards the use of English. Many have referred to the argument about the 
appropriateness of this language to Indian stories. And I hope all of us share the opinion that we can't simply use the language the way British did; that it needs remaking for our own purposes-To conquer English may be to complete the process of making ourselves free (17).

\section{Conclusion}

Like in other diasporic novels, in The Inheritance of Loss also, the characters are in search of an identity, for love and acceptance in a foreign land. But they find it difficult to locate where they belong to since a diasporic hybridity is, in the words of Radhakrishnan, "a frustrating search for constituency and a legitimate political identity" (312-313). They have developed a sense of loss though in different degrees. The characters are all victims of the so-called 'diasporic dilemmas'.

However, in the final analysis like in the case of Biju the reader also finds some hope of 'true' happiness in his supposedly reunion with his father. Though he has lost much materially and emotionally, there is a spiritual gain. It is pertinent that the novel like a foreshadowing opens with a poetic description of a serene and peaceful landscape dominated by the awe inspiring beauty of Kanchenjunga in the North East Himalayas: "All day, the colors had been those of dusk, mist moving like a water creature across the great flanks of mountains possessed of ocean shadows and depths" (1) and it also ends with an optimistic note when Sai saw the meeting of the cook and his broken son Biju taking place: "The five peaks of Kanchenjunga turned golden with the kind of luminous light that made you feel, if briefly, that truth was apparent. All you needed to do was to reach out and pluck it" (324). Desai probably wants to suggest that life is worth living in spite of all the agonies and sufferings that it brings forth in this journey. People especially from third world countries are often attracted by the material prosperity, wealth and 
comforts of the west and embark on their voyage to achieve their dreams. However, in spite of the backwardness, poverty, and illiteracy in one's own land, one can derive a sense of belonging and identity only in one's own home land. Uprooting and re-rooting in an alien land is a painful process and Desai has successfully depicted the dilemmas of her characters in their longing for true fulfillment in their lives. 
Works Cited

Ashcroft and et al, Eds. The Post- Colonial Reader. $2^{\text {nd }}$ ed. London: Rutledge, 2008

Baktin M.M. The Dialogic Imagination. Texas: University of Texas Press, 1987

Bhabha, Homi. The Location of Culture. London and New York: Rutledge, 1994

Desai, Kiran. The Inheritance of Loss, New Delhi: Penguin Books, 2006

Jayarajan, Uma. “John Peter Peterson or Jemubhai Patel?” The Uncanny Doubleness and

“Cracking" of Identity in Kiran Desai’s Inheritance of Loss" Asiatic, Vol. v, No.1, June 2011

Radhakrishnan R. "Postcoloniality and the Boundaries of Identity" in Identities eds. Linda Martin Alcoff and Edurdo Mendieta. London: Blackwell Publishing, 2003

Rushdie, Salman. Imaginary Homelands: Essays \& Criticism 1981-1991. New York: Penguin Books 1992

Spielman, David Wallace. "Solid Knowledge and Contradictions in Kiran Desai's Inheritance of Loss, 2010. www.tandfonline.com/doi:/abs/10.1080/0011161903249872, Accessed 20 June 2017

About the author

Abraham Panavelil Abraham is currently a Professor of English at the University of Nizwa, Sultanate of Oman. Earlier, Prof. Abraham had taught at Gujarat University and M. S. University of Baroda. His research interests include American/ British/Postcolonial literatures and challenges of teaching English language in the Gulf regions. He has published extensively in reputed journals and magazines. 